\title{
Thermal resistance of raffia palm reinforced concrete
}

\author{
Samson Olalekan Odeyemi (Main and Corresponding Author)
}

Department of Civil and Environmental Engineering, Kwara State University, Malete

P.M.B 1530, Malete, 23431, Kwara State (Nigeria)

samson.odeyemi@kwasu.edu.ng

https://orcid.org/0000-0001-5217-3403

\section{Zainab Tolu Giwa}

Department of Civil and Environmental Engineering, Kwara State University, Malete

P.M.B 1530, Malete, 23431, Kwara State (Nigeria)

zainabgiwa21@gmail.com

https://orcid.org/0000-0002-4447-2240

Manuscript Code: 13814

Date of Acceptance/Reception: 02.03.2021/12.05.2020

DOI: 10.7764/RDLC.20.1.5

\begin{abstract}
There are increasing interests in the usage of natural fibres as reinforcing component for concrete production due to their enormous properties such as low cost, its abundance and availability. This research examined the thermal resistance of Raffia Palm Fibre (RPF) reinforced concrete. In this study, $0 \%$ to $1 \%$ fibre content by weight of cement were incorporated in concrete and their compressive strength were tested after heating. A total number of 36 cubes were prepared, cured and tested at 28 days. Concrete cubes with $0 \%$ fibre was used as control specimen. The cubes' compressive strengths were determined at $0{ }^{\circ} \mathrm{C}, 556{ }^{\circ} \mathrm{C}$ and $659^{\circ} \mathrm{C}$ at 0 minutes, 5 minutes and 10 minutes respectively. The result revealed that workability of the concrete declined with a rise in the percentage of raffia palm. There is also a substantial surge in the compressive strength of raffia palm fibre reinforced concrete cubes (RPFRC) compared to the control concrete samples. The compressive strength of the concrete cubes decreased with the rise in temperature for the entire samples tested. It was concluded that increasing the percentage fibre content in concrete reduces the rate of loss in compressive strengths of concrete when subjected to heat.
\end{abstract}

Keywords: concrete, compressive strength, raffia palm fibre, scanning electron microscopy, thermal resistance.

Introduction

A commonly used manufactured material in the construction of a variety of structures globally is concrete (Emmanuel, Oladipo, \& Olabode, 2012; Odeyemi, Abdulwahab, Abdulsalam, \& Anifowose, 2019; S O Odeyemi, Anifowose, Oyeleke, Adeyemi, \& Bakare, 2015; Raheem \& Ibiwoye, 2018). Concrete comprises cement (binder), water, and aggregates (fine and coarse). The mixture of these components is expected to be resistant to freezing and chemical attack, workable, possess low permeability, be resistant to wearing and cheap. Steel compliments concrete since concrete is weak in tension but possess a high compressive strength. Steel is however costly in developing countries where it is mainly imported (Sharu \& Salau, 2004). The inclusion of fibers in concrete makes it isotropic, homogeneous and increases the flexural strength (Odera, Onukwuli, \& Osoka, 2011a). Whenever there is a crack in concrete, the randomly oriented fibers arrest the crack propagation, therefore, enhancing the strength of concrete (Asare, Peter, \& Francis, 2016). The inclusion of fibre in concrete have been reported to cause significant reduction of concrete pore pressure, thus preventing spalling in such concrete (Manica, Bolina, Tutikian, \& Valad, 2019). Fibres are the friendliest environmental construction material which offers stability and flexibility in designing all building structures.

Substituting manufactured building materials with wastes may proffer a much-required prospect in mitigating waste management problems (Odeyemi, Atoyebi, \& Ayo, 2020). Irrespective of the scale in which this is carried out, a high production rates will result into appreciable waste material consumption and a renewable and cheap source of raw materials for the benefitting industries (Ejeh, Abubakar, Ocholi, \& Nurudeen, 2014). Of major concern, globally, is the issue of fire outbreaks (Lennon \& Moore, 2003; Lewis, 2008; S O Odeyemi, Giwa, \& Abdulwahab, 2019). The integrity of concrete is often called to question since after such outbreak the strength of such concrete reduces substantially. Fire has considerable effect on concrete by reducing its mechanical strength and compromising user safety (Manica et al., 2019).

Raffia fibre is obtained from raffia palm. According to Robert \& Shedrack (2016); Obahiagbon (2009); Ndon (2003), the raffia fibre is soft, pliable and non-shrinking when it is wet. The generic name of raffia is 'raphis', meaning needle like, describing the pointed structure of its fruits. Raffia palm are about twenty species. A great potential abounds for the use of raffia palm products in Nigeria since the tree thrive widely Africa. It is widely available, abundant and of relatively 
low cost in the southern part of Nigeria. Several published articles are available on the use of Raffia palm in Nigeria (Ali, 2012; Esegbuyota, Akpokodje, \& Uguru, 2019; Odera, Onukwuli, \& Osoka, 2011b; Ramakrishna \& Sundararajan, 2005). The abundance, availability and cheapness of raffia palm fibre has motivated this study to determine both its physical and mechanical properties in concrete. This study explores the thermal resistance of raffia palm fibre reinforced concrete at varying temperatures.

Composite materials are multi-functional, and they offer uniqueness that cannot be gotten from discrete materials (Nyior, Aye, \& Tile, 2018; Samson Olalekan Odeyemi, Akinpelu, Atoyebi, \& Yahaya, 2017). They contain sturdy load bearing materials branded as reinforcements entrenched in a matrix of weaker materials with the reinforcements giving rigidity and strength, which supports the structural loads, while the matrix, usually in organic or inorganic forms, sustain the orientation and position of the reinforcements (Osoka, Onukwuli, \& Kamalu, 2018). Composite are unified structures formed by merging some materials with differing characteristics, compositions and form (Pathan \& Jamnu, 2012). The key benefit of using composite materials is their essential capacity to be designed to suit a specific situation. The constituents of a composite such as fibres can be combined in differing percentages to achieve an optimal material composition.

Esegbuyota, Akpokodje, \& Uguru (2019) considered the significance of raffia palm fibres on the compressive strength of solid sandcrete blocks. The sandcrete blocks were reinforced with $1 \%, 2 \%$, and $3 \%$ raffia palm fibre, and cured with irrigation method. The results obtained disclosed that fibre size had no substantial impact on the water absorption, compressive strength and rate of swelling of the blocks. But fibre volume had significant effect $(P \leq 0.05)$ on the compressive strength, water absorption and swelling rate of the blocks. The compressive strength generally reduced with an upsurge in the volume of the fibre content, while the water absorption and swelling rate of the blocks rose with a surge in volume of fibre.

According to Odera, Onukwuli, \& Osoka (2011a), using raffia palm fibres as reinforcements in cement mortar increases its flexural strength more than twice its initial strength. Their findings further revealed that raffia palm fibre gave a reasonable result when used as reinforcement in fibre-mortar roofing tiles. They recommended raffia palm fibre as a suitable alternative to more costly fibrous materials, thus, reducing the rate of ceiling and roofing materials for low-cost houses. Different researchers have investigated the usefulness of coconut fibres (coir) as a micro-reinforcement in concrete. Atoyebi, Osuolale, \& Ibitogbe (2019) investigated the behaviour of fresh and hardened concrete produced from ordinary portland cement (OPC) strengthened with coconut fibre (coir) and super plasticizer admixture in the form of liquid soap.

The flexural and compressive strengths of the coconut fibre reinforced concrete (CRFC) were evaluated at varying percentages ( $0.1-0.5 \%$ of the component of cement) of fibre. The optimal percentage of fibre for both compressive and flexural strength was determined. Their findings revealed that there was an increment in the various properties and strength of concrete when fibre was included as reinforcement, up to an optimum percentage of $31.37 \mathrm{~N} / \mathrm{mm}^{2}$ for compressive strength and $8.03 \mathrm{~N} / \mathrm{mm}^{2}$ for flexural test, before the strength began to decline.

Mortar is usually used in the building industries. Aho \& Ndububa (2015) investigated the consequence of stabilizing cement mortar with raffia palm fruit peel (RPFP) on its density, flexural and compressive strengths. Their study revealed that with a surge in the proportion of the RPFP fibre, the density and compressive strength reduced. However, a rise in the flexural strength was observed. Their findings confirmed that mortars stabilized with fibre can be employed as lightload bearing members for civil engineering works.

Raffia palm fibre can serve as a good reinforcing agent in fibre-cement mortar because it is elastic and resistant to alkaline environments. Also, its properties, availability, health-hazard free characteristic and low-cost, raffia palm fibre is suitable as a replacement for other costly fibrous materials in the building industry (Odera et al., 2011b). Though several research has been conducted on the use of raffia palm fibre in cement composite, none has studied its effect on thermal resistance in concrete. Thus, this research is aimed at determining the thermal resistance of raffia palm fibre reinforced concrete at varying temperatures. 


\section{Materials}

Materials utilized for this study are Raffia palm, cement, aggregates (both fine and coarse), and water. The Raffia palm was collected from a farmland at Oke-Onigbin, Isin Local Government of Kwara State. Ordinary Portland cement, Dangote brand, of grade 32.5R and specific gravity of 3.05, was used. Coarse aggregate of diameter size of $12.5 \mathrm{~mm}$ and fine aggregate conforming to BS EN 12620:2002+A1:2008 (BS EN 12620:2002+A1:2008, 2008) was utilized. Potable water with pH 7 was used for this work. The Raffia palm before and after shredding are shown in Figure $1(\mathrm{a})$ and (b).
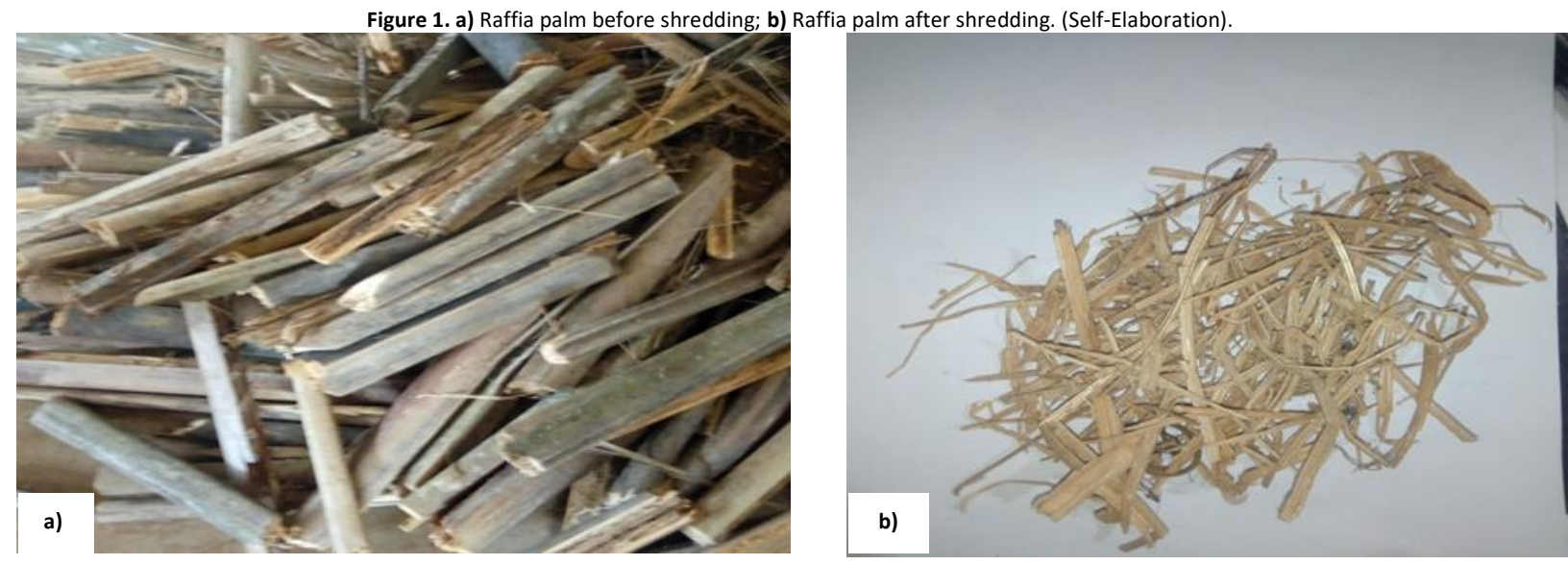

\section{Methods}

\section{Sample preparations}

Particle size distribution of the cement and fine aggregates utilized for this work was conducted as stipulated in BS EN 933-1:2012 (BS EN 933-1, 2012). The percentage of the particles passing through the sieves was plotted against the particle diameters. The fineness modulus for fine aggregate was obtained from Equation 1 while the uniformity coefficient, which reveals the grading of the aggregate, was calculated from the graph using Equation 2.

$$
\begin{gathered}
\text { Fineness modulus }=\frac{\text { Total cummulative percentage retained }}{100} \\
\qquad C_{u}=\frac{D_{60}}{D_{10}}
\end{gathered}
$$

where: $C_{u}$ is the uniformity coefficient, $D_{60}$ represents the diameter of particles matching $60 \%$ fines on the cumulative particle-size distribution curve while $D_{10}$ represents the diameter of particles matching $10 \%$ fines on the cumulative particle-size distribution curve. If the $C_{u}$ of the soil sample is less than 4.0 it can be deduced that the material sample is uniformly graded but if $C_{u}$ of the sample is greater than 4.0 the material is well graded (Bowles, 1996; Neville, 2011; Shetty, 2008).

The Raffia palm leaves were removed from the stalk. The Raffia palm fibres were shred into smaller pieces. Batching of material was done using a weighing balance. Absolute volume method was adopted for the design mix with a characteristic and target strengths of $20 \mathrm{~N} / \mathrm{mm}^{2}$ and $27 \mathrm{~N} / \mathrm{mm}^{2}$ respectively. Raffia palm fibre was added to concrete at differing percentages for the batches of the mix. Slump test was carried out on the fresh concrete mix to get the workability of the concrete samples in conformity to BS EN 12350-2 (BS EN 12350-2:2009, 2009). When the samples were demoulded, the cubes were positioned in a curing tank for 28 days. After the cubes had been cured for 28 days, their density was found as stipulated by BS EN 12390-7 (BS EN 12390-7:2009, 2009). Afterwards, they were inserted in a blast furnace, heated at a temperature of $556{ }^{\circ} \mathrm{C}$ and $659^{\circ} \mathrm{C}$ for 5 minutes and 10 minutes respectively after which they were tested for their compressive strengths following the stipulations in BS EN 12390-3 (BS EN 12390-3:2009, 2009).

The Scanning Electron Microscopy (SEM) analysis was carried out in the laboratory of the material science and engineering department, Kwara State University, Malete using a SEM ASPEX 3020 at $16.0 \mathrm{kV}$ accelerating voltage. The samples were covered in gold, utilizing Balzer's sputtering device, before inserting them under the microscope. 
Table 1 shows the mix proportion for the concrete as obtained from the designed mix calculation.

\begin{tabular}{cccccc}
\multicolumn{7}{c}{ Table 1. Proportioning of concrete components. (Self-Elaboration). } \\
\hline $\begin{array}{c}\text { Raffia Palm } \\
\text { Fibre (\%) }\end{array}$ & $\begin{array}{c}\text { Raffia Palm Fibre } \\
(\mathrm{kg})\end{array}$ & W/C Ratio & $\begin{array}{c}\text { Cement } \\
(\mathrm{Kg})\end{array}$ & $\begin{array}{c}\text { Fine } \\
\text { Aggregate }(\mathrm{Kg})\end{array}$ & $\begin{array}{c}\text { Coarse Aggregate } \\
(\mathrm{Kg})\end{array}$ \\
\hline $0 \%$ & 0 & 0.58 & 372 & 760 & 1034 \\
$0.5 \%$ & 1.86 & 0.58 & 372 & 760 & 1034 \\
$0.75 \%$ & 2.79 & 0.58 & 372 & 760 & 1034 \\
$1.0 \%$ & 3.72 & 0.58 & 372 & 760 & 1034 \\
\hline
\end{tabular}

Results and discussion

\section{Analysis of particle size distribution}

The result of the analysis of the particle size distribution for the fine aggregate is presented in Figure 2. The dimension of the aggregate range between $0.10 \mathrm{~mm}$ to $1 \mathrm{~mm}$ indicating that they fall within the category of fine and medium sand (Neville, 2011). The aggregate's fineness modulus was obtained as 2.99. The fineness modulus for fine aggregates ranges from 2.3-3.1 (BS EN 12620:2002+A1:2008, 2008). This result falls within the acceptable limit for fine aggregates. The $C_{u}=3$, this means that the fine aggregate is uniformly graded.

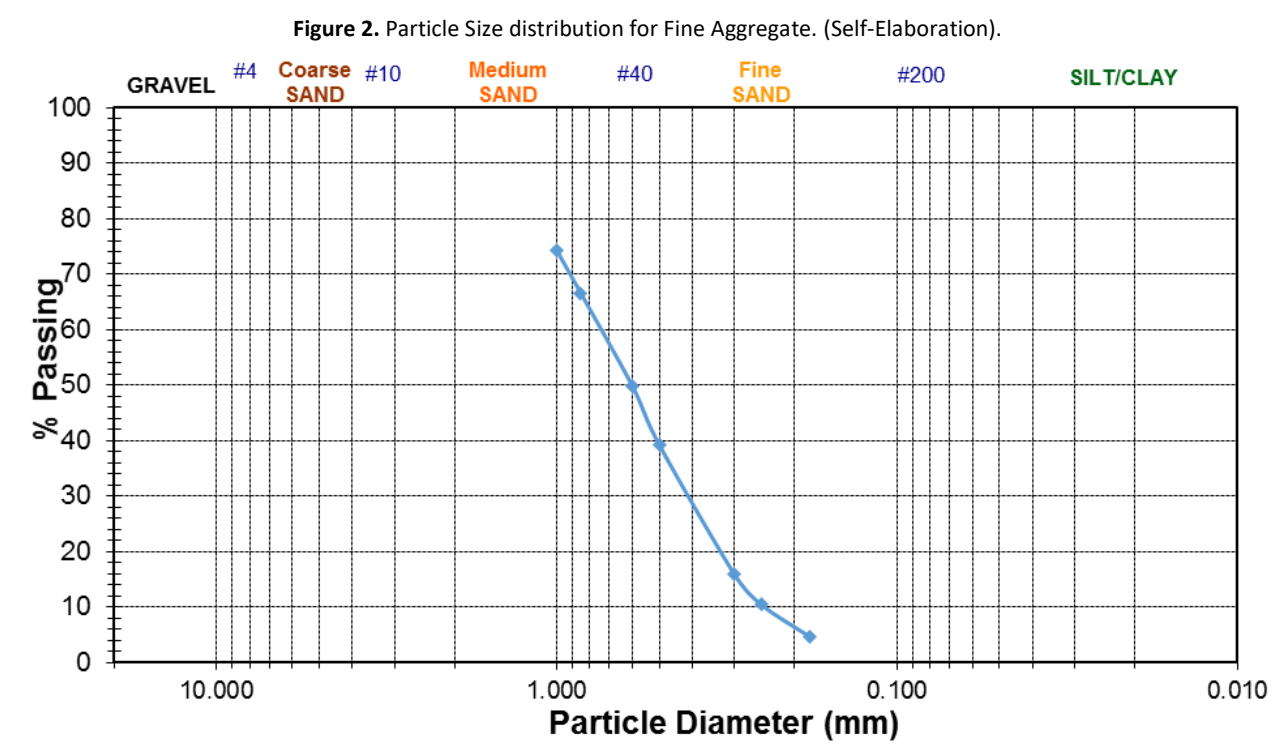

\section{Specific gravity of aggregate}

The specific gravity result for fine and coarse aggregate are presented in Table 2.

Table 2. Specific gravity of aggregates and OPC. (Self-Elaboration).

\begin{tabular}{cc} 
& Table 2. Specific gravity of aggregates and OPC. (Self-Elaboration). \\
\hline Materials & Specific gravity \\
\hline Fine aggregate & 2.61 \\
Coarse aggregate & 2.79 \\
\hline
\end{tabular}

American Concrete Institute ( $\mathrm{ACl}$ Education Bulletin, 2007) specified the range of specific gravity of aggregates to be from 2.30 to 2.90 . Therefore, the results obtained for the specific gravity for the aggregates used in this study are within the boundary for fine and coarse aggregates.

\section{Test results on fresh concrete}

The slump height values, shown in Figure 3, reduces as the proportion of raffia palm reinforcement by weight of cement increases. This shows that the concrete become inflexible as the reinforcement increases. The slump heights fall are all true slumps. This implies that the adopted water cement ratio is adequate for the concrete mix. 


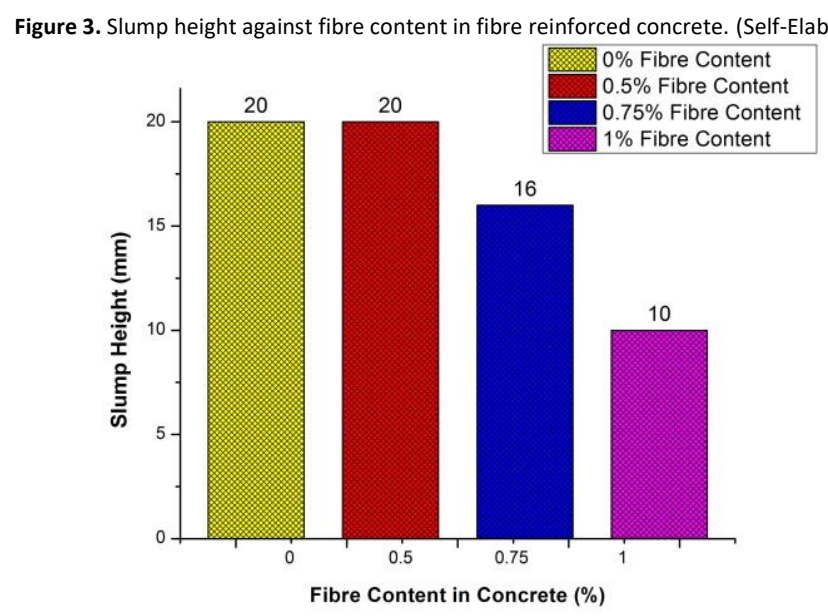

Tests on hardened concrete

\section{Density of concrete cubes}

Table 3 is a presentation of the mean density of concrete cubes containing different levels of replacement of RPF.

Table 3. Density of concrete cubes. (Self-Elaboration).

\begin{tabular}{cccc}
\hline Replacement level & \multicolumn{3}{c}{ Mean density at 28 days } \\
\cline { 2 - 4 } & No burning & $556{ }^{\circ} \mathrm{C}$ at 5 minutes & $659{ }^{\circ} \mathrm{C}$ at 10 minutes \\
\hline $0 \%$ RPF & 2384 & 2419 & 2382 \\
$0.5 \%$ RPF & 2410 & 2407 & 2350 \\
$0.75 \%$ RPF & 2401 & 2382 & 2335 \\
$1.0 \%$ RPF & 2384 & 2356 & 2314 \\
\hline
\end{tabular}

All the concrete cube samples have densities which are within the boundary of $2300 \mathrm{~kg} / \mathrm{m}^{3}-2615 \mathrm{~kg} / \mathrm{m}^{3} \mathrm{recommended}$ in BS EN 12390-7 (BS EN 12390-7:2009, 2009). However, the increase in the replacement level of the RPF resulted in the decrease in the density of the concrete. This will result in the reduction in the dead load of the structural members where such concrete is applied.

\section{Compressive strength}

Figure 4 shows the compressive strength results of the raffia palm fibre reinforced concrete. The results obtained for the control sample and all the different percentages of raffia palm fibre added to the concrete before burning all met the minimum requirement for the characteristic strength of $20 \mathrm{~N} / \mathrm{mm}^{2}$ (BS EN 1992-1-1:2004+A1:2014, 2004) and designed target mean strength of $27 \mathrm{~N} / \mathrm{mm}^{2}$ (BS EN 1992-1-1:2004+A1:2014, 2004). From Figure 4, it is evident that the compressive strength of the concrete increases as the quantity of fibre increases. The addition of $0.5 \%, 0.75 \%$ and $1 \%$ RPF increased the compressive strength of the concrete by $0 \%, 3.2 \%$ and $11.5 \%$ respectively before subjecting them to burning.

However, with the increase in temperature and duration of burning the compressive strength decreases. $1 \%$ incorporation of RPF gave $11.5 \%$ increase in the compressive strength of concrete before burning when related with concrete without fibre. After burning for 10 minutes, $1 \%$ RPF incorporation still gave $2 \%$ increase in the compressive strength when related with concrete without fibre. 
Figure 4. Compressive strength against duration of burning. (Self-Elaboration).

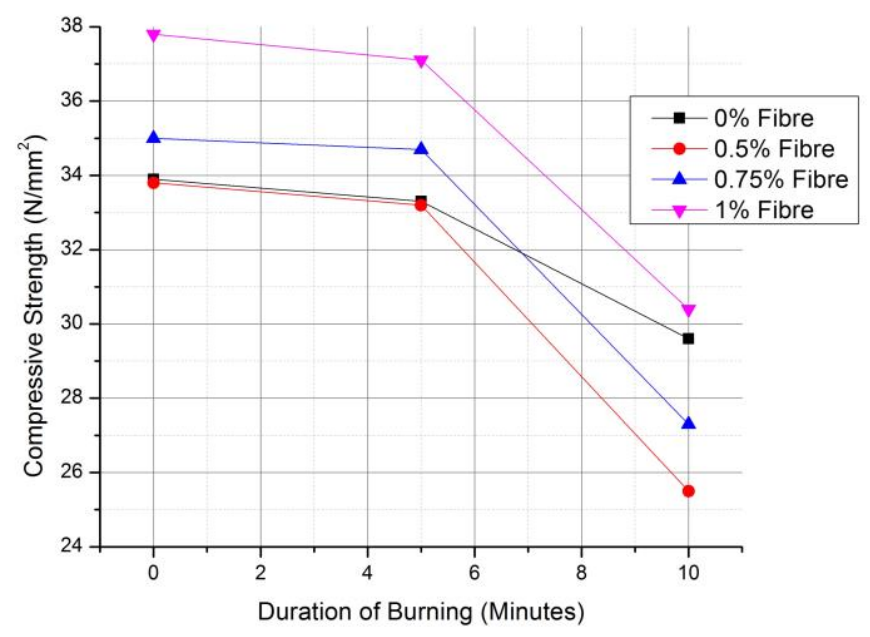

\section{Scanning electron microscopy (SEM)}

Figure 5(a-e) shows the microstructures of ceramic composite containing concrete as the matrix and raffia palm fibres at different percentages by weight as reinforcement. Morphology of the control sample in Figure 5a reveals non plain surface with depressions of different shapes and sizes. When the sample was thermally treated at $556^{\circ} \mathrm{C}$, there is a structural change perhaps due to atomic vibration of the concrete which involves jumping of an atom from a point to another. The thermally induced structural changes give rise to a new structure (Figure 5b) which appears more packed with less surface defects than that of the sample without heat treatment.

Addition of raffia palm fibres to the matrix leads to changes in the morphology of the composites as it is evidenced from Figure 5(c-e). The difference in morphological structures of the concrete/raffia palm fibres composite is an indication of variation in responses of the composites to mechanical loading as shown in Figure 6. Since all the materials were treated at the same temperature, variation in the compressive strength can be ascribed to integrity of morphological structure developed as the weight percent of the raffia palm fibres increase.

This is affirmed by the $1 \%$ fibre composite having highest degree of structural integrity when compared with others in Figure 5. Moreover, when the heat treatment temperature increased to $659^{\circ} \mathrm{C}$, the composite structures are associated with pronounced surface defects which degrade the compressive strength of the composites since the compressive strengths of all the composites thermally treated at $659^{\circ} \mathrm{C}$ are smaller than those treated at $556^{\circ} \mathrm{C}$.

This implies that increasing holding duration and temperature have bad consequence on the composite structures. It is possible that at temperature between $556^{\circ} \mathrm{C}$ and $659^{\circ} \mathrm{C}$, raffia fibres decompose and release some gases, trapped into the composites and cause porosities within the composites. Another possibility is the approach of the refractoriness within temperature range which may lead to crack formations within the composites.

Figure 5. SEM Result showing the internal microstructure of the sample burnt for 5 minutes at $556^{\circ} \mathrm{C}$ : a) $0 \%$ Replacement No burning; b) $0 \%$ Replacement at $5560 \mathrm{C}(5$ Minutes); c) $0.5 \%$ Replacement at $5560 \mathrm{C}$ (5 Minutes); d) $0.75 \%$ Replacement at 5560C (5 Minutes); e) $1 \%$ Replacement at $5560 \mathrm{C}$ (5 Minutes). (Self-Elaboration).

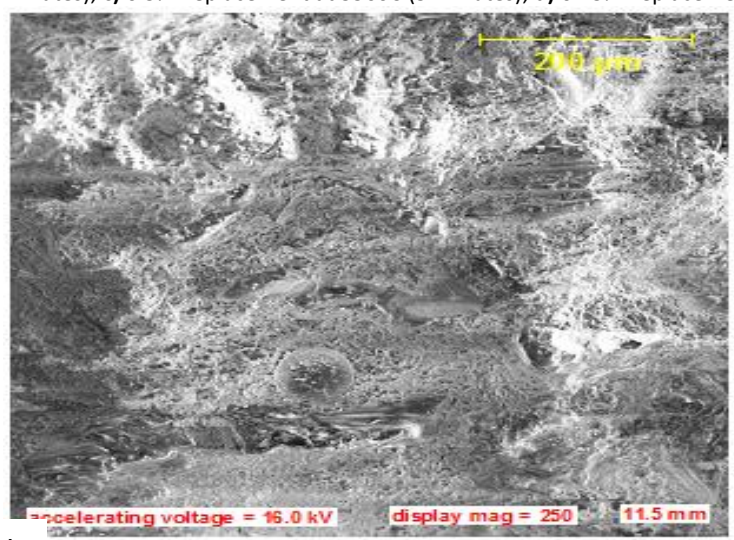

a)

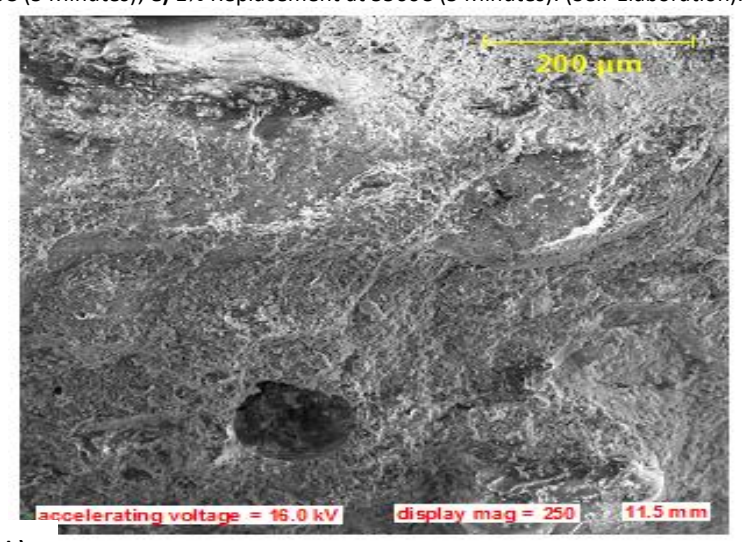

b) 


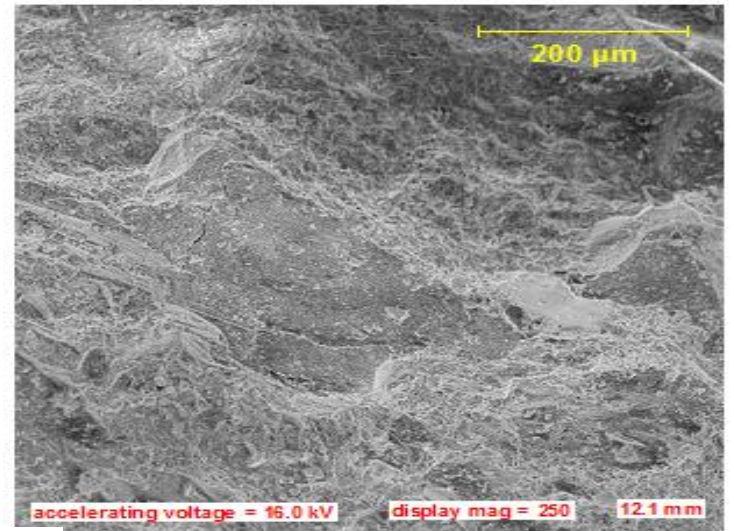

c)

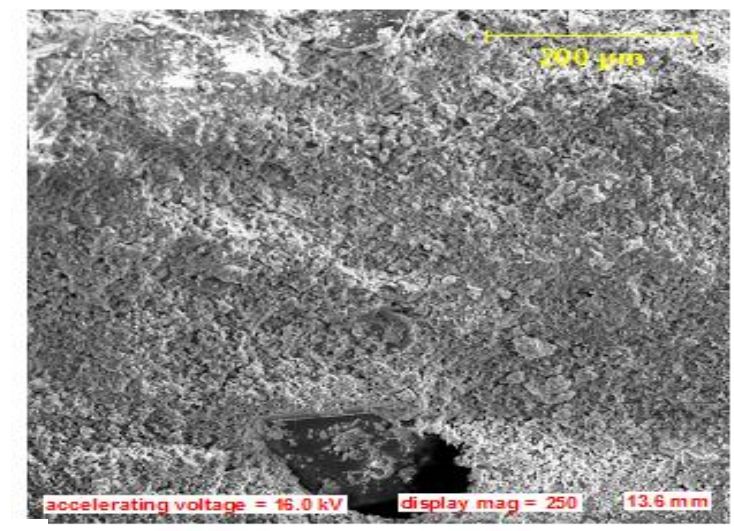

d)

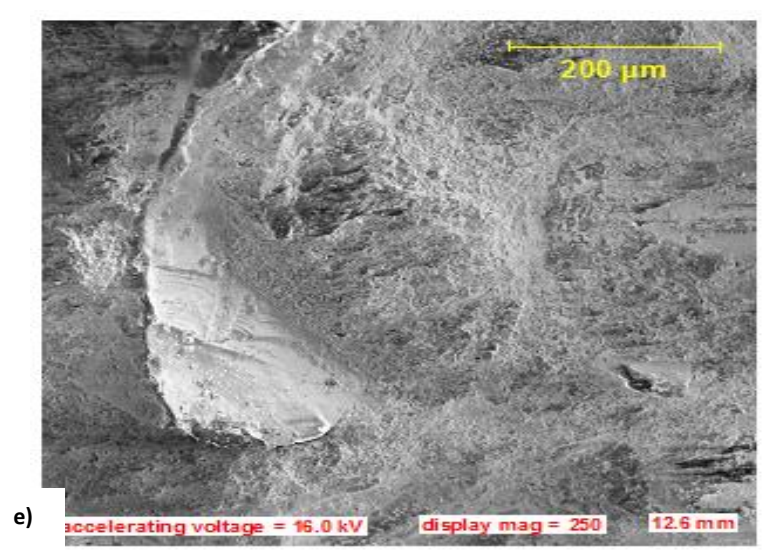

Figure 6. SEM result showing the internal microstructure of the sample burnt for 10 minutes at $659^{\circ} \mathrm{C}$ : a) $0 \%$ Replacement no burning; b) $0 \%$ Replacement at $659^{\circ} \mathrm{C}$ (10 Minutes); c) $0.5 \%$ replacement at $659^{\circ} \mathrm{C}$ (10 Minutes); d) $0.75 \%$ Replacement at $659^{\circ} \mathrm{C}\left(10\right.$ Minutes); e) $1 \%$ Replacement at $659^{\circ} \mathrm{C}(10 \mathrm{Minutes})$. (Self-Elaboration).

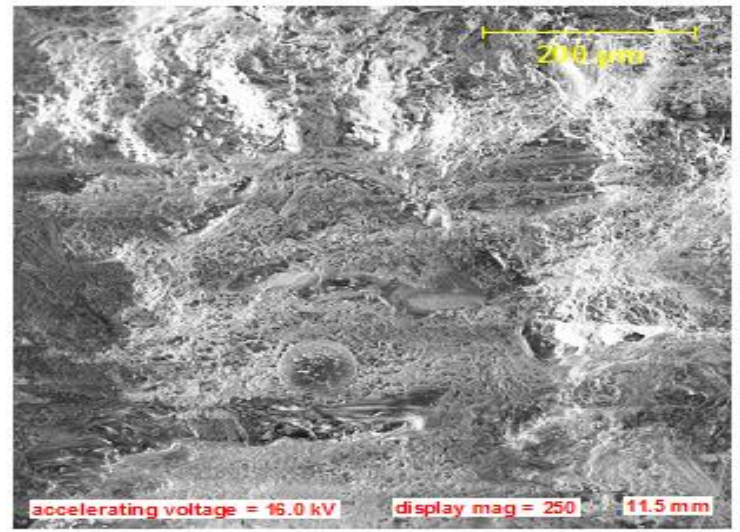

a)

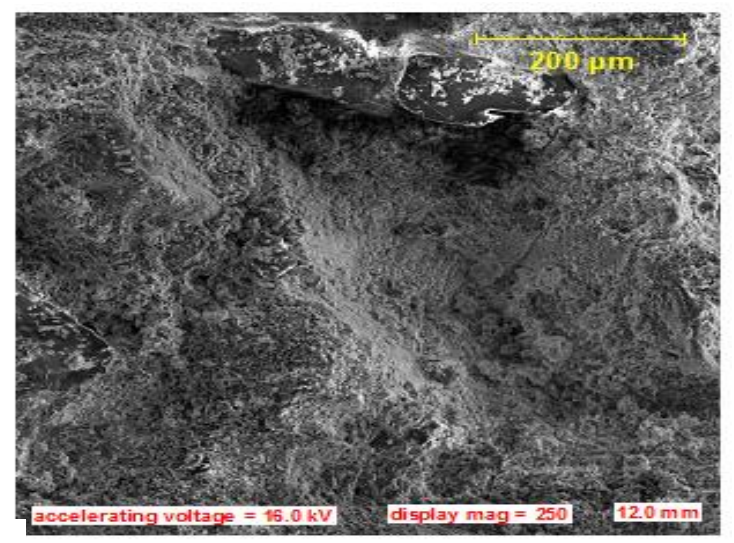

c)

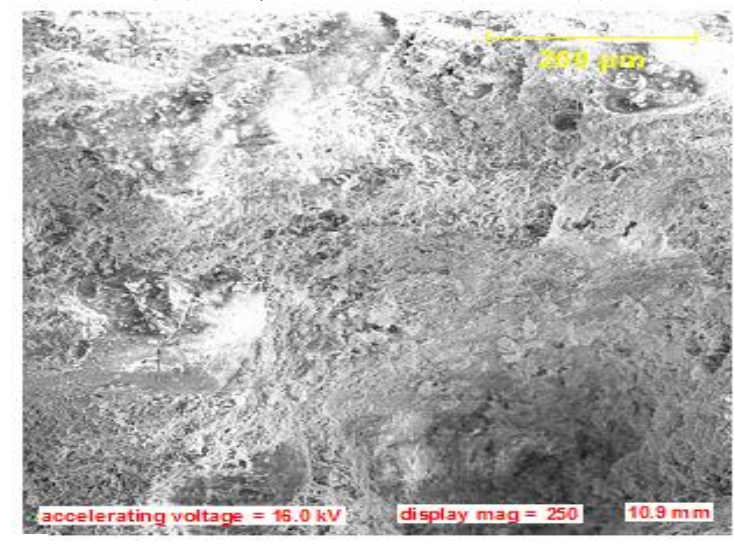

b)

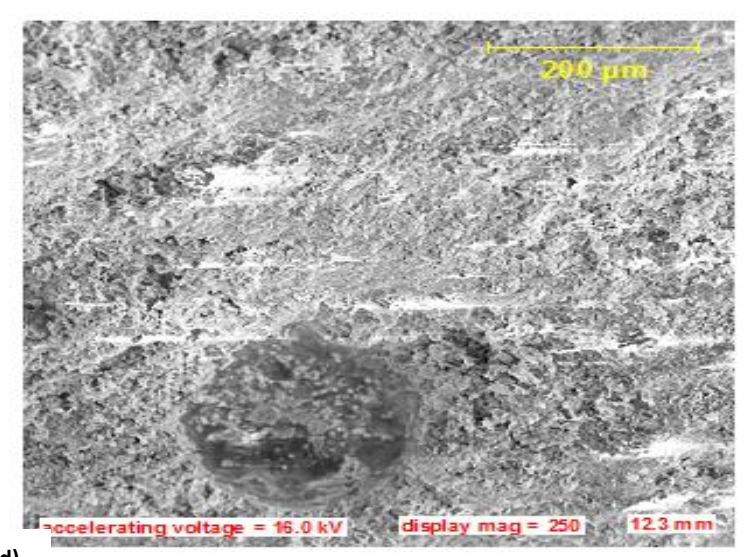
s. d) 


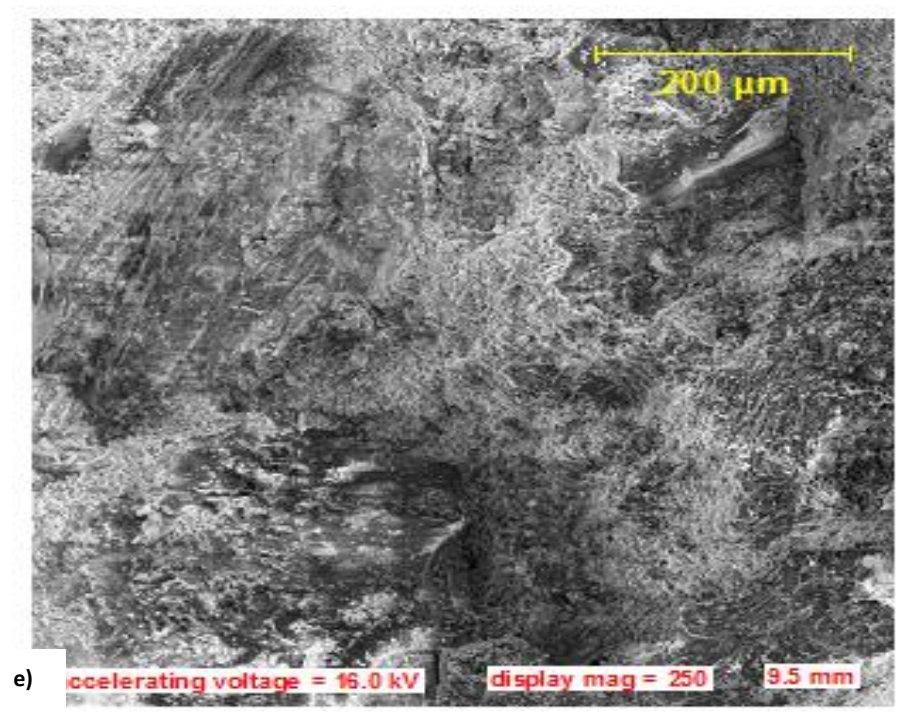

Conclusions

The inferences drawn from the study are:

- The slump height of the concrete samples reduced from $20 \mathrm{~mm}$ to $10 \mathrm{~mm}$ ( $50 \%$ reduction) with the inclusion of the fibre. Thus, the workability of concrete decreases with increase in the percentage of raffia palm fibre reinforcement.

- $1 \%$ incorporation of Raffia palm fibre gave $11.5 \%$ increase in the compressive strength of concrete before subjecting to heat. Therefore, the inclusion of RPF brings a surge in the compressive strength of concrete.

- $1 \%$ fibre incorporation gave a $2 \%$ increase in compressive strength of Raffia palm fibre reinforced concrete when related with concrete without fibre after subjecting to heat.

- The variation in the compressive strength is ascribed to the integrity of the morphological structure developed as the weight percent of the raffia palm fibres increase. This is affirmed by the $1 \%$ fibre composite having highest degree of structural integrity when compared with others.

Acknowledgement

The Authors acknowledge the help of Dr. Sefiu Bello of the Materials Science Engineering Department, Kwara State University, for his assistance in interpreting the SEM results.

References

ACl Education Bulletin. (2007). Aggregates for Concrete-Materials for Concrete Construction. Developed by Committee E-701, American Concrete Institute, 38800 Country Club Dr, Farmington Hills, Michigan, United States.

Aho, I. M., \& Ndububa, E. E. (2015) . Compressive and Flexural Strengthof Cement Mortal Stabilized with Raffia Palm Fruit Peel (RPFP). Global Journal of Engineering Research, 14, 1-7. https://doi.org/10.4314/gjer.v14i1.1

Ali, M. (2012). Natural fibres as construction materials. Journal of Civil Engineering and Construction Technology, 3(3), 80-89. https://doi.org/10.5897/JCECT11.100

Asare, K. A., Peter, P. Y., \& Francis, A. (2016). The use of Raffia Palm (Raffia Hookeri) Piassava Fibre as Reinforcement of Concrete. The International Journal of Engineering and Science, 5(6), 1-6.

Atoyebi, O. D., Osuolale, O. M., \& Ibitogbe, E. M. (2019). Strength Evaluation of Cocos nucifera Fibre Reinforced Concrete. Journal of Engineering and Applied Sciences, 14(21), 8061-8066.

Bowles, J. E. (1996). Foundation Analysis and Design. The McGraw-Hill Companies, Inc.

BS EN 12350-2:2009. (2009). Testing Fresh Concrete - Slump Test, British Standards. 
BS EN 12390-3:2009. (2009). Testing Hardened Concrete - Compressive Strength of Test Specimens, British Standards.

BS EN 12390-7:2009. (2009). Testing Hardened Concrete - Density of Hardened Concrete, British Standards.

BS EN 12620:2002+A1:2008. (2008). Specification for Aggregates from natural sources for concrete. British Standards, BSI Group Headquarters 389 Chiswick High Road, London, W4 4AL, UK, Standards Policy and Strategy Committee.

BS EN 1992-1-1:2004+A1:2014. (2014). Eurocode 2: Design of concrete structures. General rules and rules for buildings.

BS EN 933-1. (2012). Tests for Geometrical Properties of Aggregates - Part 1: Determination of Particle Size Distribution - Sieving Method.

Ejeh, S. P., Abubakar, I., Ocholi, A., \& Nurudeen, M. M. (2014). Effect neem seed husk ash on concrete strength properties. Nigerian Journal of Technology, 33(2), 163-169. https://doi.org/http://dx.doi.org/10.4314/njt.v33i2.4

Emmanuel, A. O., Oladipo, F. A., \& Olabode, O. (2012). Investigation of Salinity effect on Compressive Strength of Reinforced Concrete. Journal of Sustainable Development, 5(6), 74-82. https://doi.org/10.5539/jsd.v5n6p74

Esegbuyota, D., Akpokodje, O. I., \& Uguru, H. (2019). Physical Characteristics and Compressive Strength of Raffia Fibre Reinforced Sandcrete Blocks. Direct Research Journal of Engineering and Information Technology, 6, 1-8. https://doi.org/10.5281/zenodo.2635395

Lennon, T., \& Moore, D. (2003). The Natural Fire Safety Concept. Fire Safety Journal, 38(7), 623-643. https://doi.org/10.1016/S0379-7112(03)000286

Lewis, C. (2008). Are House Fire Changing?. The Australian Journal of Emergency Management, 23(1), 44-48.

Manica, G., Bolina, F., Tutikian, B., \& Valad, M. (2019). Analysis of the resistance to fire of solid concrete boards with polypropylene microfibers and long curing time. Revista de La Construccion, 18(3), 595-602. https://doi.org/10.7764/RDLC.18.3.595

Ndon, B. A. (2003). The Raphia Palm (1st ed.). Concept Publications, Ltd., Lagos, Nigeria.

Neville, A. M. (2011). Properties of Concrete (5th ed.). London, England: Pearson Education Limited. ISBN: 978-0-273-75580-7

Nyior, G. B., Aye, S. A., \& Tile, S. E. (2018). Study of Mechanical Properties of Raffia Palm Fibre/Groundnut Shell Reinforced Epoxy Hybrid Composites. Journal of Minerals and Materials Characterization and Engineering, 6 , https://doi.org/https://www.researchgate.net/deref/https\%3A\%2F\%2Fdoi.org\%2F10.4236\%2Fjmmce.2018.62013

Obahiagbon, F. I. (2009). A review of the origin, morphology, cultivation, economic products, health and physiological implications of raphia palm. African Journal of Food Science, 3(13), 447-453.

Odera, R. S., Onukwuli, O. D., \& Osoka, E. C. (2011a). Optimization of Flexural strength of Raffia Palm- Fibre Cement Composites. Journal of Emerging Trends in Engineering and Applied Sciences, 2(2), 294-297.

Odera, R. S., Onukwuli, O. D., \& Osoka, E. C. (2011b). Stress and strain Characteristics of Raffia Palm Fibre Under Varying Condition. International Journal of Chemical Engineering Research, 3(2), 159-166.

Odeyemi, S O, Abdulwahab, R., Abdulsalam, A. A., \& Anifowose, M. A. (2019). Bond and Flexural Strength Characteristics of Partially Replaced SelfCompacting Palm Kernel Shell Concrete. Malaysian Journal Of Civil Engineering, 31(2), 1-7.

Odeyemi, S O, Anifowose, M. A., Oyeleke, M. O., Adeyemi, A. O., \& Bakare, S. B. (2015). Effect of Calcium Chloride on the Compressive Strength of Concrete Produced from Three Brands of Nigerian Cement. American Journal of Civil Engineering (AJCE), 3(2-3), 1-5. https://doi.org/10.11648/j.ajce.s.2015030203.11

Odeyemi, S O, Atoyebi, O. D., \& Ayo, E. K. (2020). Effect of Guinea Corn Husk Ash on the Mechanical Properties of Lateritic Concrete. IOP Conference Series: Earth and Environmental Science, 445(012034), 1-11. https://doi.org/10.1088/1755-1315/445/1/012034

Odeyemi, S O, Giwa, Z. T., \& Abdulwahab, R. (2019). Building Collapse in Nigeria ( 2009- 2019 ), Causes and Remedies - A Review. USEP: Journal of Science and Engineering Production, 1(1), 123-135.

Odeyemi, Samson Olalekan, Akinpelu, M. A., Atoyebi, O. D., \& Yahaya, R. T. (2017). Determination of Load Carrying Capacity of Clay Bricks Reinforced With Straw. International Journal of Sustainable Construction Engineering \& Technology, 8(2), 2180-3242. Retrieved from http://penerbit.uthm.edu.my/ojs/index.php/IJSCET

Osoka, E. C., Onukwuli, O. D., \& Kamalu, C. I. (2018). Mechanical Property Of Selected Natural Fibre Reinforced Composites For Automobile Application. American Journal of Engineering Research, 7(5), 384-388. 
Pathan, M. A., \& Jamnu, M. A. (2012). Compressive Strength Of Conventional Concrete \& High Strength Concrete with Temperature Effect. International Journal Of Advanced Engineering Research \& Studies, 1(3), 101-102.

Raheem, A. A., \& Ibiwoye, E. O. (2018). A study of neem seed husk ash as partial replacement in concrete. International Journal of Sustainable Construction Engineering \& Technology, 9(2), 55-64. https://doi.org/10.30880/ijscet.2018.09.02.006

Ramakrishna, G., \& Sundararajan, T. (2005). Impact strength of a few natural fibre reinforced cement mortar slabs: A comparative study. Cement \& Concrete Composites, 27(5), 547-553. https://doi.org/10.1016/j.cemconcomp.2004.09.006

Robert, J., \& Shedrack, T. (2016). Investigation of Thermal Conductivity of Raphia Fibre (Piassava) from Raphia Hookeri. International Journal Of Applied Science and Mathematical Theory, 2, 10-17. ISSN 2489-009X.

Salau, A. S. \& Sharu, A.S. (2004). Behaviour of Laterised concrete column Reinforcement with bamboo strips. West Indian Journal of Engineering, 27(1), 38-49.

Shetty, M. S. (2008). Concrete Technology Theory and Practice. S. CHAND \& Company Ltd., New-Delhi, India. 